ISSN 1112-9867

Available online at http://www.jfas.info

\title{
THINKING ABOUT DEATH IN THE POETRY OF FEREIDOUN MOSHIRI
}

\author{
H. Bassak, M. Gholipour
}

Associate Professor, Persian Language and Literature Dept, Payame Noor University (PNU), 19395- 4697 Tehran, IR of Iran

Master's Degree Program Student in the Field of Persian Language \& Literature, Payame Noor University (PNU), IR of Iran

Published online: 15 May 2016

\begin{abstract}
As we know, death is eternal fate of every phenomenon and men is not an exception. We'll die soon or late. But why most of us scare of it?

Fear of death can be classified into two sections: death of euthanization; men considers death and does not believe in life after death. Hence they would like to stay in this world.

Fear from bad deeds: some men believe in death but are fearful of death due to bad deeds. In the first section death is complete devastation but if we consider death a new birth and believe that passing from this world we will reach to another world with full of blessings, then we' 11 make fun of such description of death. The second group who did wrong deeds. They must know that God is so generous and paved the way for regret of bad people. Death is as Moshiri says death is a solution for leaving life problems behind and to reach to eternal relaxation. Not only he consider it disgusting but also he regards it calm.
\end{abstract}

Keywords: Fereidoun Moshiri, poem divan, death ideology, phobia, world and after death life

Author Correspondence, e-mail: bassak@pnu.ac.ir

doi: http://dx.doi.org/10.4314/jfas.v8i3s.126

Journal of Fundamental and Applied Sciences is licensed under a Creative Commons Attribution-NonCommercial 4.0 International License. Libraries Resource Directory. We are listed under Research Associations category. 


\section{INTRODUCTION}

Death should be accepted as a blessing and we should not be fearful of it. Fear of death is a psychological factor and causes anxiety of individuals since with the arrival of death all the love to this world will be over and on the other hand there is no sign of eternal happiness available, men are not aware of their future and this is worrisome (Ghassemi, 2007, 39).

\section{FEREIDOUN MOSHIRI, HIS STYLE}

he is a new one. He seeks to distribute his poems to a wider class of our society (Moshiri, 1998, $11)$.

\section{DEATH FROM ASPECT OF MOSHIRI}

Death is not bad as it is for many. (Pirlee, 2006. A kind of sleepiness: during our life we sleep a lot and awaken. Death soul be considered as a sleepiness, hence Moshiri considers it sleepiness and says why do you fear from this sweet dream? (Moshiri, 2000: 179). Death is closer to you than your shadow. Death symbol is on your forearm. The world behind you is twisting. (Nahjoblabaghah, 2010, 263) death is truth. Why do you consider it a fake story?).

\section{DEATH IS NOT FAKE}

It will hug us in the end. My son you know that you were born for life after death. To leave this world and not for staying. Yes, we are passengers in this world, the lighter your burden the easier to your trip.

\section{LIFE AFTER DEATH}

Molavi says dead people regret why they did not do more good deeds, they could have done much better with good deeds (Mohseni, 2012”: 135). Don't think that disappointment swallows me. Don't say it is a sad story. I think Moshiri likened position and wealth to a bad sadness.

You should not increase your bad deeds through gathering up wealth. Are not all the wines for relaxation of soul? You are not looking for relaxation? Why are you fearful of death then? (Moshiri, 2000: 107). Yes, death will be great for you if you follow God`s orders and establish your life as God ordered. 
Where can you find a better relation than death? This wine here solves your problems temporality but the calmness you receive from death is eternal. Be ready before you die, since in that moment your wishes die and you won`t be able to ask God for forgiveness.

\section{6- DEATH IS A HEAVEN}

It is eternal the world is here and there. If people stick to this world, death will be hard for them. Ad death is easy for those who are not much interested in this world (Kensi, 10.)

Death is the door to eternity. In this world there is no sing of freedom. Reminding of death aware us of temporary life in this world. Death is not an independent reality and makes you lose this life. Rahimian, 2010: 87)

It is a nice deed to finish our life period before death (Metring, 2009, 152).

\section{CONCLUSION}

We must know that with good deeds, we provide the situation for welcoming a nice death. With these arguments we may respond research question easily: what's reason behind death fear? We must consider death like birth of an embryo as a secondary birth and believe that with passing from this hard life we will enter a world which is full of calmness, then we will not fear death. Makarem Shirazi, 1997, 30). Does death mean end of life? Eternal life starts with death. In fact it can be argued that real and full life is followed by death. Can we defeat death? If we make our life based on God's orders and act as God orders then in death time there will be no fear, deeds such as good deeds, being nice with others, preventing form bad deeds. Since we know that good deeds make us de easier. What's approach of Fereidoun Moshiri in dealing with death? He considers death exit of this world. Soon or late you will die. That time, your wealth and power will not profit you. What makes you feel free is being good.

\section{REFERENCES}

Nahjolbalaghe, 2010. Translated by Dashti, Ashkzar Publication.

Pirli, Jeuvani (1979). Last letters of those sentences to death. Translated by Houshang Vaziri, Tehran: Kharazmi Publication.

Rahimian, Saeed (2010), death fear in Attar`s works. Two scientific-research articles in moral literatures of Alzahra University. Pp.81-87. 
RAfiei, Ghazvini, Seyyed Abolhasan (2000). Life after death. Ghom. Hadise-emrouz Publication.

C Solumon, Robert. Malpas, Jef (2005) beauty of death in words of morals. Ghom, Azad-mehr Publication.

Shabani fard, Mohammad Javad (2010), beauty of death in words of mystics. Ghom. Moje-elm Publication.

Sadeghi, Hadi. (2013), death ideology. Moral and medical history Iranian magazine. Sixth period. No. 1. March. pp. 24-27.

Omid Hossein (2010). Omid Persian Dictionary). Tehran: Parmis Publication.

Fallah, Morteza (2008). Three looks to death in Persian Literature. Two scientific-research articles in Yazd University. No.11. autumn and winter... pp. 226-245.

Feizi, Karim (2006). Hundred men, hundred death. Ghom. Religious media publication.

Ghasemi, Ali mohhammad. (2006). World after death. Ghom. Imam Khomeini Publication Center.

Kensi, Heidar (2008). Death amazing stories, v.1. Ghom. Fatih Khabir Publication.

Metreling, Mors. (2009). Life and death gate. Translated by Zabihollah Mansouri. Tehran. Negarestan ketab Publication.

Mohseni, Shahbaz. (2002) death from view of Molavi. Scientific-research articles of Persian language and literature, Sanandaj University, .No.13, winter, pp. 130-133.

Moshiri, Fereidoun (2000). Eternal beauty) Tehran, Sokhan publication.

Moshiri, Fereidoun (2001). Reflection of morning person`s soul, Tehran, Cheshmeh Publication. Meghdadi Esfahani, Ali (1994). Sign of non-sings. Ehran, Jomhouri Pubclcation.

Makaram, Shirazi, Naser. (1997). Life after death. Ghom, Sorouz Publication.

\section{How to cite this article:}

Bassak H, Gholipour M. Thinking about death in the poetry of fereidoun moshiri. J. Fundam. Appl. Sci., 2016, 8(3S), 1059-1062. 